\title{
A first shallow firn-core record from Glaciar La Ollada, Cerro Mercedario, central Argentine Andes
}

\author{
David BOLIUS, ${ }^{1}$ Margit SCHWIKOWSKI, ${ }^{1}$ Theo JENK, ${ }^{1,2}$ Heinz W. GÄGGELER, ${ }^{1,2}$ \\ Gino CASASSA, ${ }^{3}$ Andrés RIVERA ${ }^{3,4}$ \\ ${ }^{1}$ Paul Scherrer Institut, CH-5232 Villigen PSI, Switzerland \\ E-mail: margit.schwikowski@psi.ch \\ ${ }^{2}$ Department of Chemistry and Biochemistry, University of Bern, Freiestrasse 3, CH-3012 Bern, Switzerland \\ ${ }^{3}$ Centro de Estudios Científicos, Av. Arturo Prat 514, Casilla 1469, Valdivia, Chile \\ ${ }^{4}$ Laboratorio de Glaciología, Departamento de Geografía, Universidad de Chile, Marcoleta 250, Casilla 3387, Santiago, Chile
}

\begin{abstract}
In January 2003, shallow firn cores were recovered from Glaciar Esmeralda on Cerro del Plomo $\left(33^{\circ} 14^{\prime} \mathrm{S}, 70^{\circ} 13^{\prime} \mathrm{W}\right.$; $5300 \mathrm{ma.s.l}$.), central Chile, and from Glaciar La Ollada on Cerro Mercedario $\left(31^{\circ} 58^{\prime} \mathrm{S}, 7^{\circ} 07^{\prime} \mathrm{W} ; 6070 \mathrm{~m}\right.$ a.s.l.), Argentina, in order to find a suitable archive for paleoclimate reconstruction in a region strongly influenced by the El Niño-Southern Oscillation. In the area between $28^{\circ} \mathrm{S}$ and $35^{\circ} \mathrm{S}$, the amount of winter precipitation is significantly correlated to the Southern Oscillation Index, with higher values during El Niño years. Glaciochemical analysis indicates that the paleo-record at Glaciar La Ollada is well preserved, whereas at Glaciar Esmeralda the record is strongly influenced by meltwater formation and percolation. A preliminary dating of the Mercedario core by annual-layer counting results in a time-span of 17 years (1986-2002), yielding an average annual net accumulation of $0.45 \mathrm{~m}$ w.e.
\end{abstract}

\section{INTRODUCTION}

Reconstruction of climatic variability on annual, interannual, decadal and millennial timescales based on ice cores retrieved in the South American Andes has a long tradition. The mountain chain is roughly $7000 \mathrm{~km}$ long and has an average height of $4000 \mathrm{~m}$. Many mountain glaciers exist, some of which have proved to contain valuable climate archives, such as Quelccaya (Thompson and others, 1985) and Huascarán (Thompson and others, 1995) which was the first glacier outside the polar regions to provide a climate record extending to the late glacial stage. However, most of the ice-core sites have been selected within the tropical part of the Andes $\left(10^{\circ} \mathrm{N}-18^{\circ} \mathrm{S}\right)$ which lies within the easterly trade-wind circulation, so the moisture comes from the tropical Atlantic Ocean. The region between $18^{\circ} \mathrm{S}$ and $28^{\circ} \mathrm{S}$ is very arid (see Fig. 1 ) and only a few small glaciers exist, despite the high elevation of the mountain chain, with several peaks exceeding $6000 \mathrm{~m}$. There, the formation of glaciers is limited by the low amount of precipitation, whereas in most high mountain areas the limitation is temperature (Kull and Grosjean, 2000). South of $28^{\circ} \mathrm{S}$, the climate is increasingly influenced by the westerlies bringing moisture from the Pacific. Precipitation on the western side of the Andes (e.g. as observed in Santiago de Chile) mainly falls in the austral winter (May-August), when the subtropical anticyclone retreats northwards. The eastern side of the mountain chain is wind-shaded; precipitation is relatively low and falls in the austral summer related to the tropical circulation (e.g. in Mendoza, Argentina).

Although the El Niño-Southern Oscillation (ENSO) influences precipitation over the entire coast of South America, the impact on Andean glaciers is most direct between $28^{\circ} \mathrm{S}$ and $35^{\circ} \mathrm{S}$, where the Pacific acts as the moisture source. The amount of winter precipitation in this area is significantly correlated to the Southern Oscillation Index (SOI) (Aceituno, 1988), with higher values during
El Niño years. At altitudes between 1380 and $3600 \mathrm{~m}$, above-average snow accumulation was observed in the Andean sector between $30^{\circ} \mathrm{S}$ and $35^{\circ} \mathrm{S}$ when the sea surface temperature anomaly in the Niño 3 region surpassed $+1^{\circ} \mathrm{C}$ during austral winter (May-August) (Escobar and Aceituno, 1998). South of $35^{\circ} \mathrm{S}$, it is generally more humid and the influence of ENSO on precipitation declines, becoming anticorrelated in Patagonia, with precipitation decreasing by about $15 \%$ during strong El Niño years between $45^{\circ} \mathrm{S}$ and $55^{\circ} \mathrm{S}$ (Schneider and Gies, 2004). An influence of ENSO on precipitation was also observed in ice cores from tropical South America, but there above-average sea surface temperatures across the equatorial Pacific Ocean coincide with lower accumulation rates and/or less negative $\delta^{18} \mathrm{O}$ (Henderson and others, 1999; Bradley and others, 2003; Hoffmann and others, 2003; Vuille and others, 2003a, b). The moisture flux of Atlantic origin therefore seems to be remotely controlled by the conditions in the Pacific.

Hence, glaciers between $28^{\circ} \mathrm{S}$ and $35^{\circ} \mathrm{S}$ are expected to record a strong ENSO signal and are therefore potential paleoclimatic archives for revealing information about ENSO in the past. The only ice core that has been recovered here was drilled on Cerro Tapado $\left(30^{\circ} \mathrm{S}\right)$. Much was learned from this record about sublimation of snow modulating the chemical signal (Ginot and others, 2001). Variations in $\delta^{18} \mathrm{O}$ were ascribed to alternating humid and dry phases related to El Niño events (Ginot and others, 2002). However, the record spanned only a short time period due to a limited glacier thickness $(36 \mathrm{~m})$. Therefore the obvious next step was to search for a thicker glacier presumably going further back in time in the geographic vicinity of Cerro Tapado.

Unfortunately, only a few potential ice-core sites exist here: Cerro Potro $\left(28^{\circ} \mathrm{S}\right)$ is very close to the so-called 'dry axis' and strongly influenced by sublimation of snow (complicating the interpretation of records), as indicated by the presence of large 'penitentes' (snow sculptures that form under very strong sublimation) (personal communication 
from U. Schotterer, 1998). Agua Negra glacier (30 S), only a few kilometres away from Cerro Tapado, is too low in elevation (4600-5200 m; Milana and Maturano, 1999), and on Cerro Olivares $\left(30^{\circ} \mathrm{S}\right.$, accessible from Agua Negra pass) only a relict glacier exists in the caldera. The study presented here was carried out to investigate the suitability of two glaciers as climate archives: Glaciar Esmeralda on Cerro del Plomo $\left(33^{\circ}\right.$ S; 5300 m a.s.I.; see Fig. 1), Chile, and Glaciar La Ollada on Cerro Mercedario ( $32^{\circ}$ S; 6070 ma.s.l.), Argentina. Cerro del Plomo is close to Santiago de Chile and can be reached from the skiing area 'La Parva' within 3 days walk. Mercedario is about $80 \mathrm{~km}$ north of Aconcagua, the highest mountain in the Americas. Access leads through a remote area of Argentina, with Mendoza and San Juan being the nearest cities.

Mean January (austral mid-summer) temperature at the nearest high-altitude meteorological station, Cristo Redentor $\left(32.82^{\circ} \mathrm{S}, 70.07^{\circ} \mathrm{W} ; 3852 \mathrm{~m}\right.$ a.s.I. $)$, is $4^{\circ} \mathrm{C}$. Using a standard lapse rate $\left(6.5^{\circ} \mathrm{C}(1000 \mathrm{~m})^{-1}\right)$, a mean January temperature of $-6^{\circ} \mathrm{C}$ and $-11^{\circ} \mathrm{C}$ for Cerro del Plomo and Cerro Mercedario, respectively, could be assumed.

\section{METHODS}

\subsection{Drilling campaigns}

In December 2000 a first glaciological and chemical survey was performed on Glaciar Esmeralda on Cerro del Plomo, central Chile $\left(33^{\circ} 14^{\prime} \mathrm{S}, 70^{\circ} 13^{\prime} \mathrm{W} ; 5300 \mathrm{~m}\right.$ a.s.l.). The glacier surface was flat and no penitentes were observed. Nevertheless, concentrations of ionic species in snow samples from a pit study showed enrichment in the surface layer attributable to sublimation such that this post-depositional effect has to be taken into account. Radar measurements of the glacier thickness were performed on two profiles on the upper part of the glacier. Overall, Glaciar Esmeralda seemed to be a suitable candidate for bearing an ice archive.

In January 2003, during an 8 day field campaign, a shallow core was retrieved from Glaciar Esmeralda, using the lightweight, portable drilling device 'FELICS small' (Ginot and others, 2002). Whereas the first four core segments $(2.5 \mathrm{~m})$ consisted of homogeneous firn, superimposed ice was encountered from this depth onwards. Drilling was stopped after $5.5 \mathrm{~m}$ when nine core segments had been retrieved. The segments were put into polyethylene bags and carried down to the camp at $4200 \mathrm{~m}$ a.s.l. early in the day (temperatures $<0^{\circ} \mathrm{C}$ ). From there on, they were cooled with dry ice until they were shipped to Switzerland in a frozen condition.

A few days after drilling on Cerro del Plomo, Glaciar La Ollada on Cerro Mercedario, Argentina, $\left(31^{\circ} 58^{\prime} \mathrm{S}\right.$, $70^{\circ} 07^{\prime} \mathrm{W} ; 6070 \mathrm{~m}$ a.s.l.) was approached. From the highest point accessible by car $(2100 \mathrm{~m})$, mules were used to carry the equipment. The tongue of Glaciar La Ollada extends downwards to approximately $5700 \mathrm{ma.s.l.,}$ but no end moraine was obvious. Around the center of the glacier, radar measurements of the ice thickness were performed on a near-circular traverse. In a flat area where the deepest ice exists, a $13.5 \mathrm{~m}$ long shallow core was drilled at $6070 \mathrm{~m}$ a.s.l. (20 core segments). The firn was compact and homogeneous. Additionally, a set of nine accumulation stakes were mounted on the glacier surface and their position was determined by global positioning system (GPS). The samples were carried to $4200 \mathrm{~m}$ a.s.l. early in

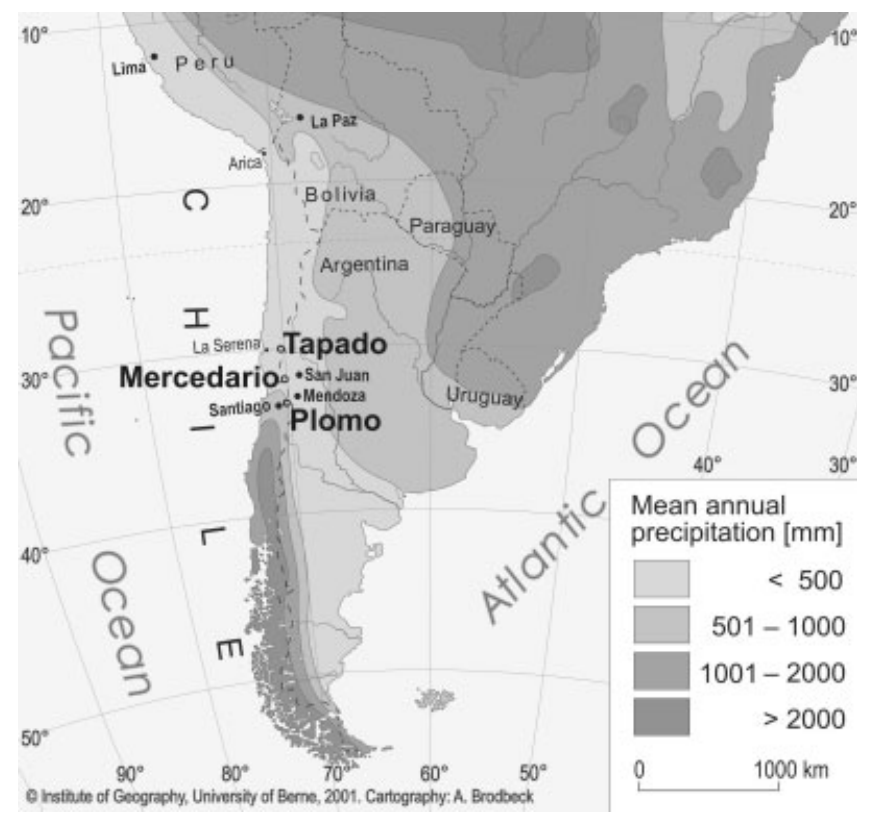

Fig. 1. Map of southern South America showing the geographical location of the two drilling sites on Cerro del Plomo and Cerro Mercedario. Mean annual precipitation amount is indicated by the gray scale. The map is adapted from Veit (2000).

the morning. From there on, they were cooled with dry ice and transported down to the valley by mules. Unfortunately, this rough transport damaged some of the core segments, leading to gaps in the data. The samples arrived in Switzerland in a frozen condition.

In February 2004, a deep-drilling campaign was attempted. Due to persistent bad weather, the transport of the drilling equipment up to the glacier was delayed several times and the mules did not reach the highest point theoretically accessible to them (5900 ma.s.l.). Consequently the drilling could not be started. Accumulation rates at the stakes and their precise positions by differential GPS could be determined and a meteorological station was run for 3 days at the lower part of the glacier (5800 m a.s.l.).

\subsection{Radar survey}

The radar system used at both sites is a portable highfrequency impulse type, applied successfully to glaciers of north-central Chile, Patagonia and Antarctica (Rivera and Casassa, 2002). The transmitter was a Narod model (Narod and Clarke, 1994), powered by a $12 \mathrm{~V}$ battery, which generates a pulse of $1100 \mathrm{~V}$, a rise time $<2 \mathrm{~ns}$ and a pulse repetition rate of 512 pulses $\mathrm{s}^{-1}$. Two $8 \mathrm{~m}$ long half-dipole antennae loaded with resistors were connected to the transmitter, generating an electromagnetic wave with a central frequency of $\sim 5 \mathrm{MHz}$. Wires were inserted inside webbing tape, thus protecting the antennae and allowing their use as regular mountain ropes. The receiver consisted of a Tektronics THS-720 digital storage oscilloscope, connected to the receiving antennae (of the same characteristics as the transmitting antennae) by means of a balun. Data were stored in the field with a Husky MP 2500 portable PC connected to the oscilloscope through the RS-232 port. Averaging of 16 traces was performed using the oscilloscope, storing one averaged trace every $4 \mathrm{~s}$.

Surface coordinates were recorded every $1 \mathrm{~s}$ by differential GPS using two GPS receivers (Trimble Geoexplorer II), 
a
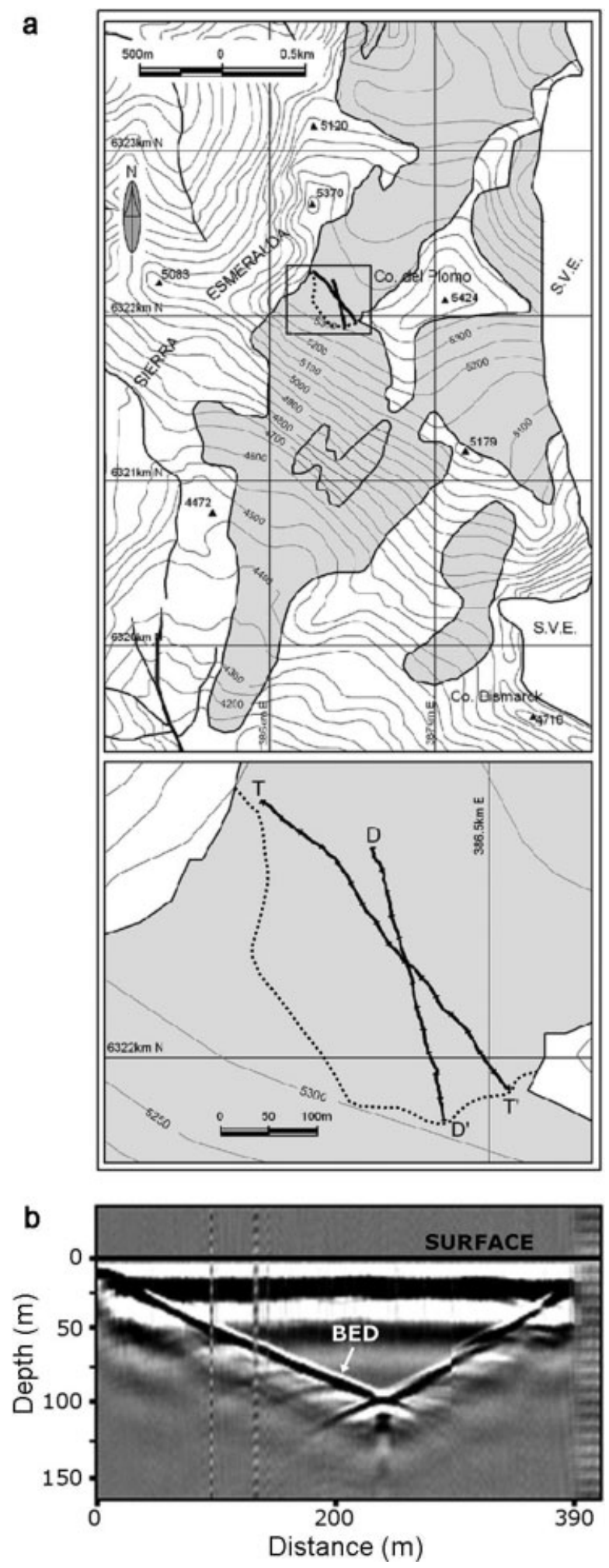

Fig. 2. (a) Map showing the position of the transverse $\left(\mathrm{TT}^{\prime}\right)$ and diagonal $\left(\mathrm{DD}^{\prime}\right)$ radar profiles obtained on Glaciar Esmeralda, Cerro del Plomo, in December 2000. Glacier extensions are taken from the 1:50000 scale map of Instituto Geográfico Militar, and include some areas of rock covered by snow. Esmeralda and El Plomo glaciers are now separated by a rocky ridge at $\sim 5350 \mathrm{~m}$ a.s.I., indicated by the dashed line. The map is adapted from Rivera and others (2001). (b) Non-migrated raster image of radar data corresponding to the transverse profile $\mathrm{TT}^{\prime}$ in (a). The glacier surface (time zero) appears flat because it has not been corrected using the GPS elevation data. The glacier bed is the V-shaped reflection which appears as a transition from gray to white on the image, with a maximum non-migrated depth of $92 \mathrm{~m}$ at the center of the valley. The figure is adapted from Rivera and others (2001).

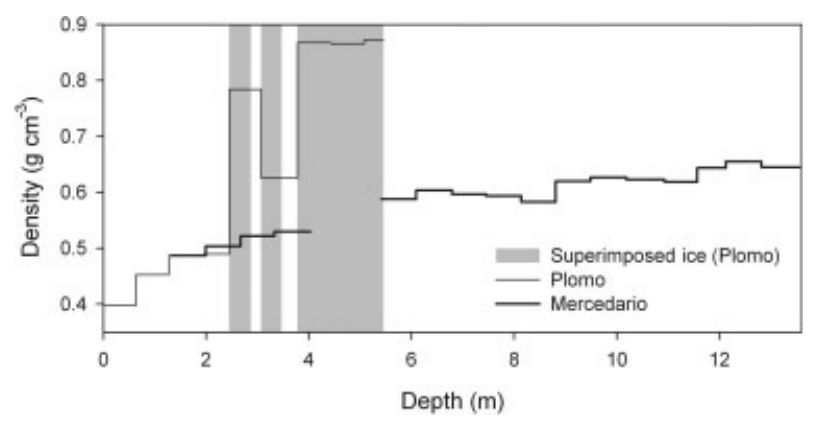

Fig. 3. Firn density vs depth of the shallow cores from Cerro del Plomo and Cerro Mercedario. Superimposed ice layers in the Plomo core are indicated by gray bars.

with single-frequency coarse-acquisition code and baselines $<500 \mathrm{~m}$, which gave an accuracy of $<1 \mathrm{~m}$ in horizontal coordinates, and $<2 \mathrm{~m}$ in elevation.

\subsection{Chemical analysis}

The two shallow cores were processed at $-20^{\circ} \mathrm{C}$ in the cold room. A detailed visual stratigraphy was recorded over the entire length of the two cores. The core segments were weighed, photographed and cut with a band-saw, such that the outer part was removed and the inner part, which was contamination-free, was sampled at a spatial resolution of $2.5 \mathrm{~cm}$. Individual samples were transferred into pre-cleaned containers and stored at $-20^{\circ} \mathrm{C}$. The samples were then melted and analyzed for major ions $\left(\mathrm{Na}^{+}, \mathrm{NH}_{4}{ }^{+}, \mathrm{K}^{+}, \mathrm{Mg}^{2+}\right.$, $\mathrm{Ca}^{2+}, \mathrm{F}^{-}, \mathrm{CH}_{3} \mathrm{COO}^{-}, \mathrm{HCOO}^{-}, \mathrm{CH}_{3} \mathrm{SO}_{3}{ }^{-}, \mathrm{Cl}^{-}, \mathrm{NO}_{3}{ }^{-}, \mathrm{SO}_{4}{ }^{2-}$ ) by ion chromatography using standard procedures (Eichler and others, 2000), as well as for stable oxygen isotopes $\left(\delta^{18} \mathrm{O}\right) . \delta^{18} \mathrm{O}$ analyses were carried out by pyrolysis of the samples at $1450^{\circ} \mathrm{C}$ in a glassy carbon reactor, to produce carbon monoxide (CO). The subsequent measurement of the relative proportions of ${ }^{12} \mathrm{C}^{16} \mathrm{O}$ and ${ }^{12} \mathrm{C}^{18} \mathrm{O}$ was done by standard isotope-ratio mass spectrometry (Delta Plus $\mathrm{XL}$, Finnigan MAT). $\delta^{18} \mathrm{O}$ is defined as the per mil difference between the sample composition and the Standard Mean Ocean Water (SMOW). The precision of the measurements was $\pm 0.2 \%$.

\section{RESULTS}

Two radar profiles 390 and $290 \mathrm{~m}$ long, respectively, were measured at the upper part of Glaciar Esmeralda (Fig. 2a), at $\sim 5330 \mathrm{~m}$ a.s.l. They showed a V-shaped (valley) glacier bed, with a maximum unmigrated thickness of $92 \mathrm{~m}$ of ice in profile $\mathrm{TT}^{\prime}$ (Fig. 2a) and $99 \mathrm{~m}$ in profile $\mathrm{DD}^{\prime}$ (Fig. 2a), as shown by a raster display of the radar data in Figure $2 \mathrm{~b}$. The surface gradient is small in this section of the glacier, with an average slope of $3 \%$ for the diagonal profile ( $\mathrm{DD}^{\prime}$ in Fig. 2a) and $5 \%$ for the transverse profile (TT' in Fig. 2a). Based on the radar data (e.g. Fig. 2b), bed gradients are much larger, up to $\sim 60 \%$, so that geometrical distortions of the bed echoes are important, which can be corrected by threedimensional (3-D) migration of the data. Two-dimensional (2-D) migration was performed with a Kirchoff algorithm. As expected, the bed appears as a U-shaped valley in the 2-D migrated profiles (not shown), with two-way travel times which are about $18 \%$ larger than the non-migrated travel times, and migrated ice-thickness values about $8 \%$ larger than the non-migrated values. Maximum ice thickness 

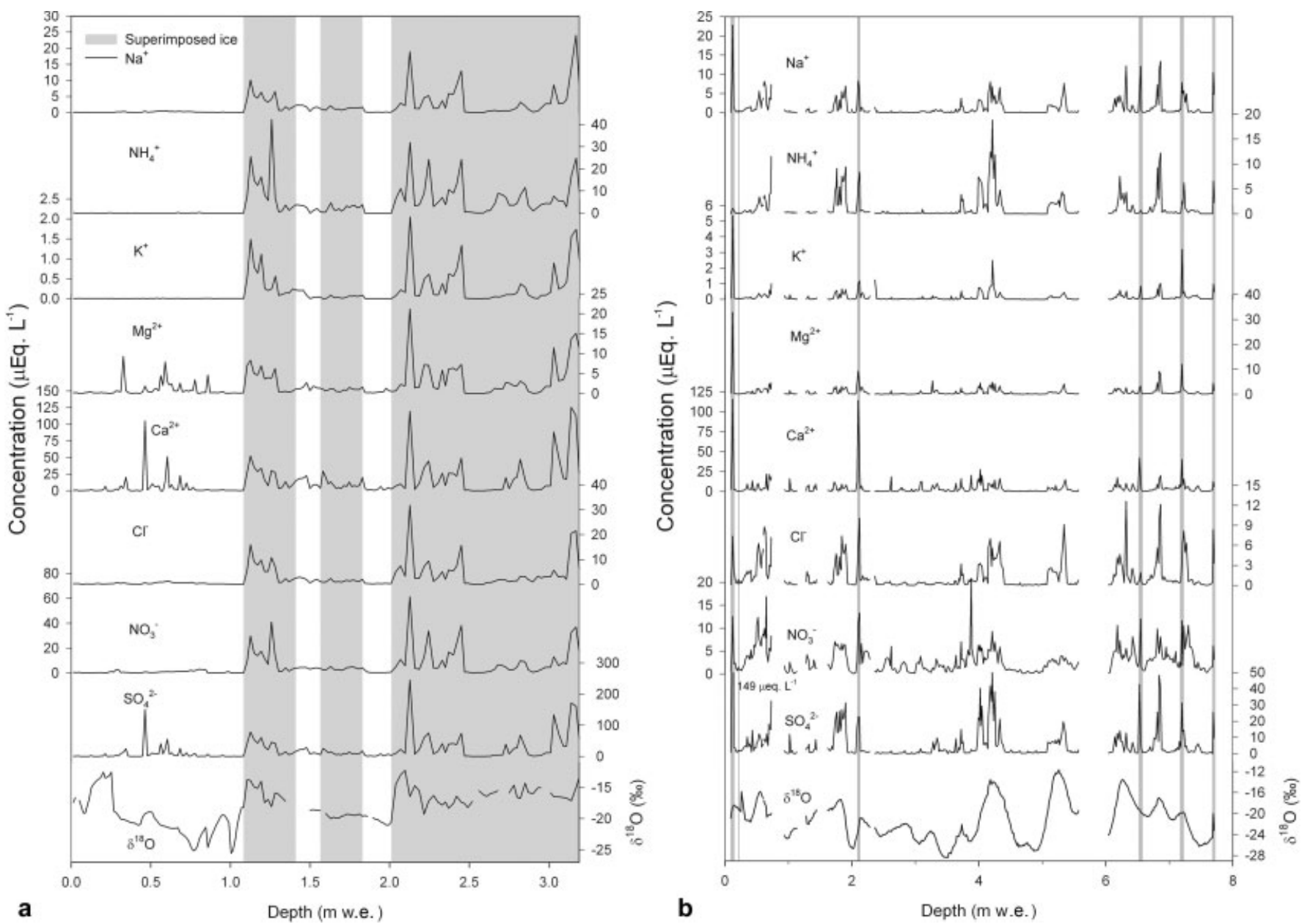

Fig. 4. (a) Major-ion concentration and $\delta^{18} \mathrm{O}$ records from Cerro del Plomo. Superimposed ice layers are indicated by gray bars. (b) Majorion concentration and $\delta^{18} \mathrm{O}$ records from Cerro Mercedario. Gray bars indicate the presence of layers with visible coarse particles. Data gaps are due to core damage during transport.

measured at Glaciar Esmeralda is therefore $\sim 107 \mathrm{~m}$ $( \pm 13 \%)$. The precision of the radar results was assessed by comparing the migrated ice thickness at the intersection of both profiles of Figure 2a.

The firn density on Glaciar Esmeralda is influenced by the presence of superimposed ice that was found starting at $2.5 \mathrm{~m}$ depth (Fig. 3). The first four core segments consist of firn with low density $\left(<0.5 \mathrm{~g} \mathrm{~cm}^{-3}\right)$ and show the expected density increase due to compaction. The last three core segments consist only of superimposed ice, as indicated by their high density close to $0.9 \mathrm{~g} \mathrm{~cm}^{-3}$. Thus, Glaciar Esmeralda is strongly influenced by formation and refreezing of meltwater. Concentrations of major ions are also affected by this post-depositional process. They are much lower in the upper $2.5 \mathrm{~m}$ (firn) where percolating water has removed the soluble species (see Fig. 4a). At the firn-ice boundary, where meltwater refroze and formed the superimposed ice, the concentrations suddenly increase as dissolved ions are trapped. Generally, mean concentrations of ionic species are high compared to concentrations at Cerro Mercedario and Cerro Tapado (Table 1). This might reflect the closer proximity to anthropogenic emission sources such as the city of Santiago, since the concentrations of $\mathrm{SO}_{4}{ }^{2-}, \mathrm{NO}_{3}{ }^{-}$ and $\mathrm{NH}_{4}{ }^{+}$are especially elevated. The $\delta^{18} \mathrm{O}$ record also seems to be affected by meltwater percolation, indicated by a smoothing of the signal below $1 \mathrm{~m}$ w.e. depth (Fig. 4a).

At Glaciar La Ollada on Cerro Mercedario (Fig. 5a) the shallow core was drilled at the deepest measured part of the glacier with an estimated depth of $137 \mathrm{~m}$ ( $\pm 13 \%$ ) (Fig. 5b). The increase of density with depth is steady $\left(0.4 \mathrm{~g} \mathrm{~cm}^{-3}\right.$ at the surface, $0.65 \mathrm{~g} \mathrm{~cm}^{-3}$ at $13.5 \mathrm{~m}$ depth; Fig. 3). The core consisted of compact firn with only a few minor ice lenses

Table 1. Mean concentrations of major ions $\left(\mu \mathrm{Eq} \mathrm{L}^{-1}\right)$ and mean $\delta^{18} \mathrm{O}(\%)$ of the shallow cores from Cerro del Plomo and Cerro Mercedario compared to values at Cerro Tapado (time period 1999-1986)

\begin{tabular}{|c|c|c|c|c|c|c|c|c|c|}
\hline Core & $\mathrm{Na}^{+}$ & $\mathrm{NH}_{4}^{+}$ & $\mathrm{K}^{+}$ & $\mathrm{Mg}^{2+}$ & $\mathrm{Ca}^{2+}$ & $\mathrm{Cl}^{-}$ & $\mathrm{NO}_{3}^{-}$ & $\mathrm{SO}_{4}{ }^{2-}$ & $\delta^{18} \mathrm{O}$ \\
\hline Mercedario & 2.36 & 1.07 & 0.16 & 0.90 & 3.96 & 1.25 & 2.82 & 5.14 & -21.4 \\
\hline Plomo & 1.54 & 3.09 & 0.14 & 1.86 & 11.24 & 2.15 & 4.53 & 17.28 & -18.6 \\
\hline Tapado (0-5.4 m) & 1.60 & 1.17 & 0.37 & 0.68 & 9.76 & 1.90 & 3.11 & 8.55 & -18.8 \\
\hline
\end{tabular}




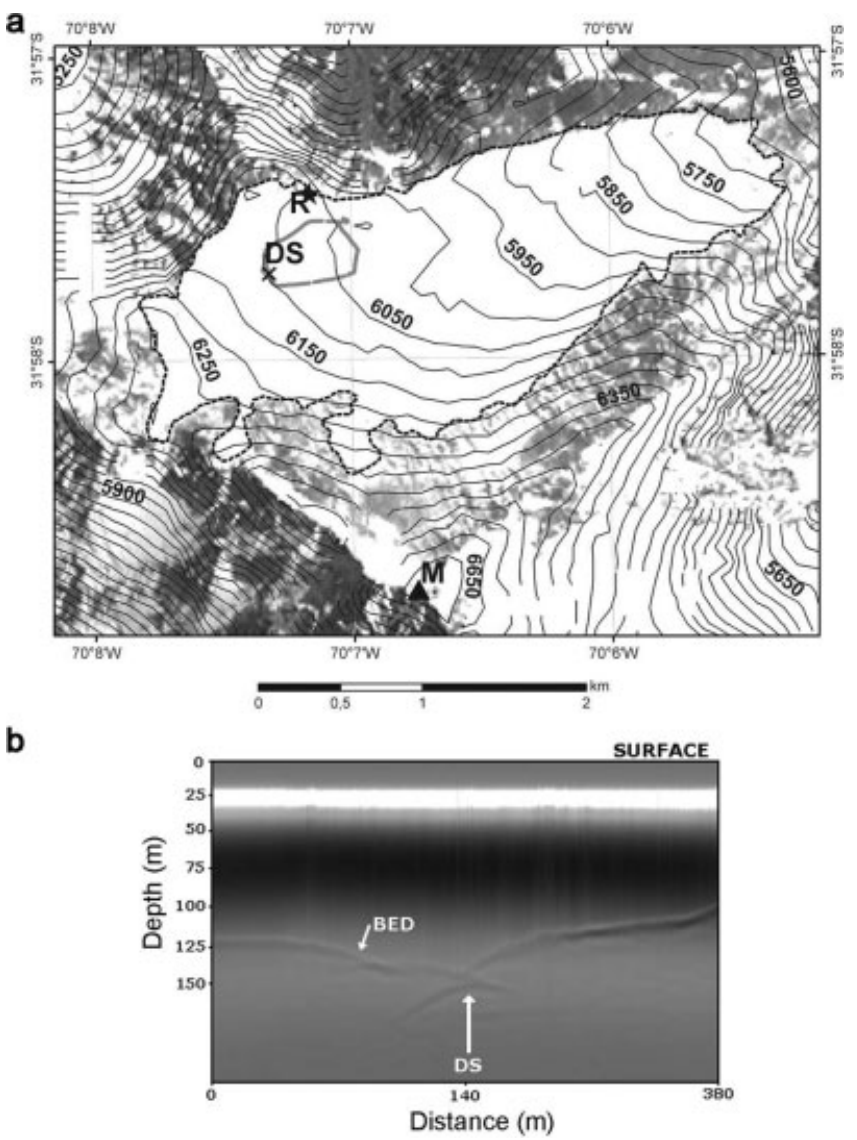

Fig. 5. (a) Glaciar La Ollada, Cerro Mercedario. Gray-scale composite of bands 1-3 of a Landsat Enhanced Thematic Mapper Plus (ETM+) image at $14.25 \mathrm{~m}$ resolution acquired on 28 February 2000 (Earth Science Data Interface at the Global Land Cover Facility, University of Maryland). Contour lines at $50 \mathrm{~m}$ interval were derived with a cubic-spline interpolation method using the Shuttle Radar Topography Mission (SRTM) digital elevation model of February 2000 at $90 \mathrm{~m}$ horizontal resolution. Elevation data are expressed as ellipsoidal heights. Orthometric or sea-level heights for the area are $33 \mathrm{~m}$ lower than the ellipsoidal heights according to the EGM96 geoidal model. $M$ is the summit of Mercedario, with a $90 \mathrm{~m}$ pixel SRTM ellipsoidal height of $6701 \mathrm{~m}$. $\mathrm{R}$ is the base station on rock used as the 2003 reference GPS site. DS is the 2003 drilling site. The 2003 radar profile is shown as a gray near-concentric line. (b) Radar profile of the vicinity of the 2003 drilling site (DS) on Glaciar La Ollada. The topmost edge of the profile corresponds to the ice surface. DS is the deepest point within the profile, with an estimated non-migrated depth of $137 \pm 18 \mathrm{~m}$.

(all thinner than $1 \mathrm{~cm}$ ). Concentrations of major ions (e.g. $\mathrm{SO}_{4}{ }^{2-}$ or $\mathrm{Ca}^{2+}$ ) span several orders of magnitude and are strongly correlated to each other (Fig. 4b). Six layers with visible coarse inorganic particles were found with individual pieces having diameters up to $2 \mathrm{~mm}$. They show up in the major-ion record as concentration peaks (Fig. 4b), since the particles were partially dissolved when the samples were melted. The $\delta^{18} \mathrm{O}$ record reveals strong fluctuations ranging from $-11.6 \%$ to $-28.3 \%$, with a mean value of $-21.4 \%$ o (Fig. 4b). Maxima in the $\delta^{18} \mathrm{O}$ signal tend to coincide with high concentrations of major ions. This is best documented for the $\mathrm{SO}_{4}{ }^{2-}$ record (Fig. 6).

At three stakes placed within $100 \mathrm{~m}$ of the drilling site, a mean accumulation of $78 \mathrm{~cm}$ of snow was observed from February 2003 to February 2004, with values ranging from 62 to $88 \mathrm{~cm}$ of snow. The remaining six stakes could not be found, presumably because they were covered by snow. The observed accumulation is therefore a minimum estimate. Night-time temperatures recorded by the meteorological station on the glacier at $5800 \mathrm{~m}$ a.s.l. ranged between $-12^{\circ} \mathrm{C}$ and $-20^{\circ} \mathrm{C}$. Daytime temperatures were not recorded reliably due to technical problems of the station. Relative humidity ranged from $10 \%$ to $90 \%$.

\section{DISCUSSION}

\subsection{Seasonality of precipitation and sublimation}

Because of the strong influence of melting on the glaciochemical record, Glaciar Esmeralda is considered unsuitable as a paleoclimate archive. The discussion will therefore focus on the results from the Mercedario core. The fluctuations in the Mercedario $\delta^{18} \mathrm{O}$ record are assumed to reflect variations in temperature during the different seasons. Thus, minima (more negative values) in the $\delta^{18} \mathrm{O}$ record are attributed to austral winter precipitation (June-August), and maxima to austral summer (December-February). Fluctuations in the concentration of major ions match with the $\delta^{18} \mathrm{O}$ record such that high concentrations coincide with high values of $\delta^{18} \mathrm{O}$ attributable to austral summer precipitation. All major ions show this behavior as illustrated for $\mathrm{SO}_{4}{ }^{2-}$ (Fig. 6). This supports the idea of seasonality as the driving force behind the observed fluctuations, as summer snow is expected to show increased ion concentrations compared to winter snow. Such a control of high-altitude aerosol concentrations by the seasonally variable intensity of vertical mixing has been studied intensively in the European Alps (Baltensperger and others, 1997), and the process is also assumed to be relevant in this subtropical region. This assumption is corroborated by the fact that formation of convective clouds in the afternoon was observed several times in austral summer on Plomo and Mercedario.

The second process probably leading to enrichment of chemical species in snow is sublimation. This process is also more important during summer because of high solar insolation and low relative humidity of the air, the two main factors driving sublimation. It was shown experimentally on Cerro Tapado that snow sublimation is a very important post-depositional process in the subtropical Andes, modulating the glaciochemical record (Ginot and others, 2001). Irreversibly deposited ionic species (e.g. $\mathrm{SO}_{4}{ }^{2-}$ or $\mathrm{Cl}^{-}$) are enriched in the topmost few centimeters of the surface when the snow evaporates during the dry season. This is very pronounced at the Cerro Tapado, located near the dry axis. The effect becomes visible in the chemical record, where several narrow peaks indicate enrichment as illustrated in the example of $\mathrm{Cl}^{-}$in Figure $7 . \mathrm{Cl}^{-}$was selected because this ion is not strongly influenced by dry deposition (as would be the case for $\mathrm{Ca}^{2+}$ ) nor is it easily released from the snow in a volatile form at this glacier site (Ginot and others, 2001). In Figure 7 it can be recognized that $\mathrm{Cl}^{-}$peaks in the record from Mercedario are much broader, whereas many more 'spikes' exist in the Cerro Tapado record. This suggests that sublimation modulates the glaciochemical record more strongly on Cerro Tapado than on Mercedario. This assumption is in agreement with increased humidity and a less pronounced dry season expected at Mercedario, located $150 \mathrm{~km}$ to the south of Cerro Tapado and thus further away from the dry axis. The difference in solar radiation between Cerro Mercedario and Cerro Tapado is small due to geographical proximity and cannot explain the different 


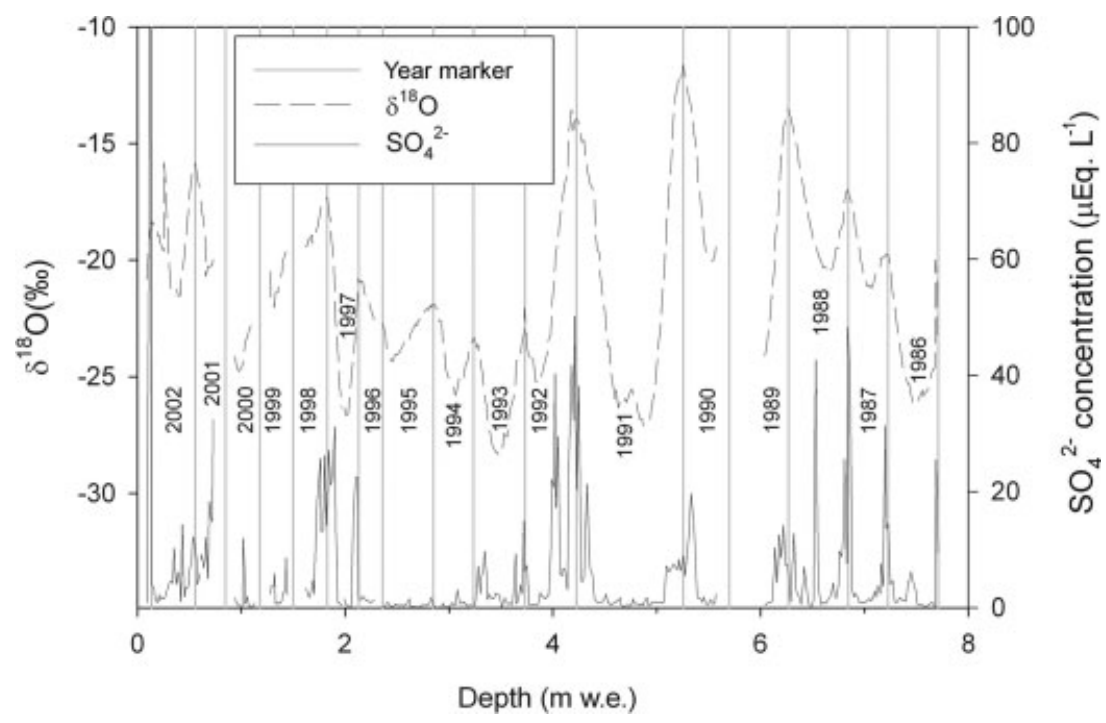

Fig. 6. Mercedario $\mathrm{SO}_{4}{ }^{2-}$ concentration, $\delta^{18} \mathrm{O}$ record and suggested annual layers.

strength of sublimation at the two sites. The different shapes of the peaks cannot be due, either, to an unequal corecutting resolution, as this was comparable for both cores.

Winter snowfall was expected to be the dominant source of precipitation in this region, as this type of pattern was typical for Cerro Tapado. However, the observed fluctuations at Mercedario suggest that precipitation also occurs in summer. This was confirmed when the deep-drilling campaign in February 2004 failed because heavy snowfall prevented the mules from reaching the highest camp accessible to them (5900 ma.s.l.). Nevertheless, most precipitation falls in winter. This is suggested by the $\delta^{18} \mathrm{O}$ record showing broader winter minima compared to narrow summer maxima (Fig. 6). Accordingly, the $\delta^{18} \mathrm{O}$ frequency distribution is skewed towards more negative values. The finding of a less pronounced dry season and a generally more humid atmosphere at Cerro Mercedario than at Cerro Tapado is in agreement with precipitation data from Santiago de Chile $\left(33^{\circ} \mathrm{S}\right)$ and Pisco Elqui $\left(30^{\circ} \mathrm{S}\right)$, both about $80 \mathrm{~km}$ from the coast. The north-south gradient in atmospheric humidity is reflected in small amounts of summer precipitation in Santiago de Chile, whereas this season is completely dry in Pisco Elqui (Fig. 8). More summer precipitation than in Santiago was found at the higherelevation sites Punta de Vacas (2416 ma.s.l.), Puente del Inca (2720 ma.s.I.) and Cristo Redentor (3862 ma.s.l.) (Videla, 1997), all located in the Andean mountain range close to Aconcagua $\left(33^{\circ} \mathrm{S}\right)$. The increasing amount of summer precipitation with elevation might be due to lifting of air masses from the west, containing some humidity, or moisture advection from the east. This region forms part of the transition area between trade winds and westerlies. In San Juan, Argentina, $\left(32^{\circ} \mathrm{S}\right)$ situated east of the Andes, on the other hand, the opposite pattern is found, with maximum amounts in summer, indicating an Atlantic moisture source.

The annual net accumulation rate on Cerro Mercedario ( $0.45 \mathrm{~m}$ w.e.; see below) is higher than on Cerro Tapado (0.31 $\mathrm{m}$ w.e.; Ginot and others, 2002). The $\delta^{18} \mathrm{O}$ signal in the Cerro Tapado core does not show seasonal variations (Fig. 9), due to the absence of summer accumulation (Ginot and others, 2002). In fact, in the rare event of summer precipitation on Cerro Tapado, this snow is lost by sublimation. The preservation of winter and summer accumulation at Cerro Mercedario and a smaller influence of post-depositional processes lead to a simpler interpretation of the glaciochemical record resulting in better identification of annual layers.
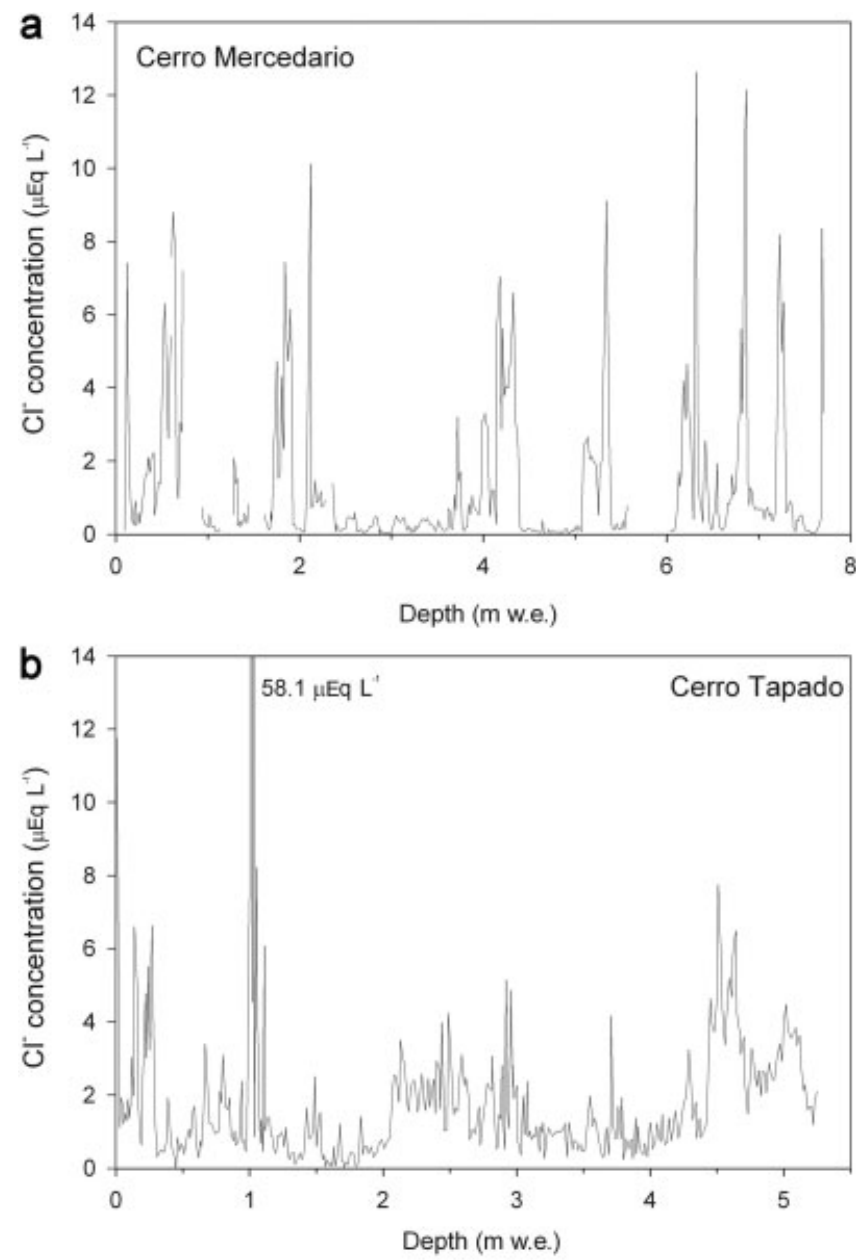

Fig. 7. $\mathrm{Cl}^{-}$records of Cerro Mercedario (a) and Cerro Tapado (b), representing a comparable time interval. 

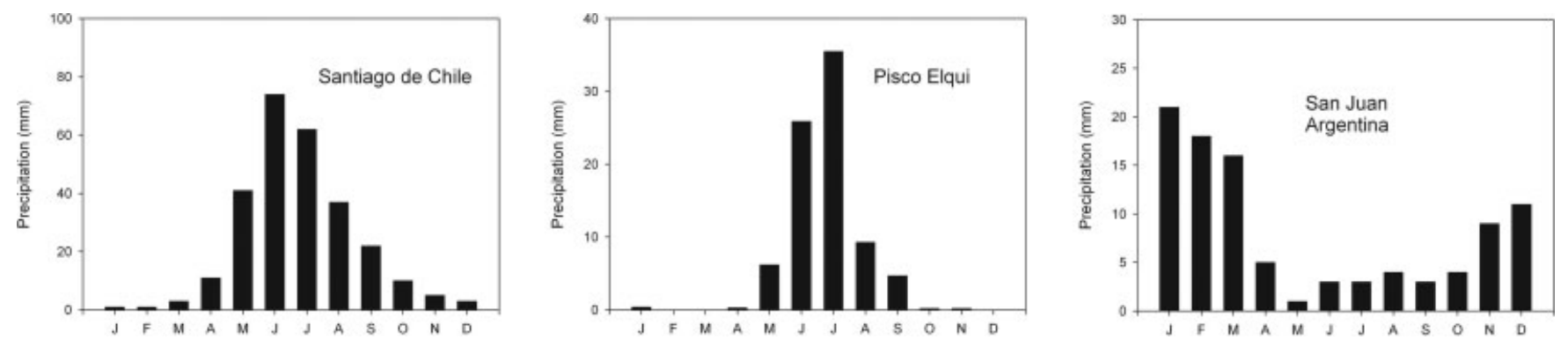

Fig. 8. Seasonal cycle of precipitation at Santiago de Chile $\left(33^{\circ} \mathrm{S}\right)$, Pisco Elqui $\left(30^{\circ} \mathrm{S}\right)$ and San Juan, Argentina $\left(32^{\circ} \mathrm{S}\right)$. Data are averages for the time period 1961-2003 and were compiled from the Global Historical Climatology Network (Vose and others, 1992).

\subsection{Preliminary dating and net accumulation}

A preliminary dating of the Mercedario core was obtained by annual-layer counting using the minima in the $\delta^{18} \mathrm{O}$ record as indicated in Figure 6 . The resulting time-span covered by the core is 17 years (1986-2002), yielding an average annual net accumulation of $0.45 \mathrm{~m}$ w.e. This value is in good agreement with the observed snow accumulation at the three stakes for the period February 2003-February 2004. More negative $\delta^{18} \mathrm{O}$ values in the Mercedario core seem to occur during known El Niño events (in 1997, 1993, 1991 and 1986; Fig. 9). Whether this is coincidence or not, and what possible mechanisms could be responsible for such an effect, will be subject to future investigations. Above-average accumulation in El Niño years was expected to occur on Mercedario, as this was reported for nearby Glaciar Piloto (Leiva, 1999) and Glaciar Echaurren (Escobar and others, 1995) and also for Cerro Tapado. At Cerro Mercedario this is particularly obvious for the years 1986 and 1991.

The dating relies only on annual-layer counting based on fluctuations in the $\delta^{18} \mathrm{O}$ and the major-ion concentration records and must therefore be regarded as preliminary. Moreover, the layer counting is hampered by gaps in the records due to damage to the firn-core material during transportation. Independent dating methods such as ${ }^{210} \mathrm{~Pb}$ dating (Crozaz and Langway, 1966; Gäggeler and others, 1983) or the use of the tritium activity maximum in 1964 as a reference horizon could not be applied in this study due to the limited time-span of the core.

\subsection{Influence of meltwater formation and percolation}

As discussed above, huge layers of superimposed ice were found in the core from Cerro del Plomo. They indicate that the glacier is strongly influenced by meltwater formation and percolation. In the Cerro Mercedario core, on the other hand, very few and thin ice layers were found. Thus, meltwater formation is not an important post-depositional process here. Most of the ice lenses match with maxima in the $\delta^{18} \mathrm{O}$ record of Cerro Mercedario. This suggests that meltwater, which is produced in austral summer when air temperatures are highest, does not percolate deeply before it refreezes. Thus, the drilling site on Cerro Mercedario is located in the upper percolation zone near the dry-snow line (Paterson, 1994), indicating a very low mean annual air temperature.

The strong discrepancy in meltwater formation is attributed to the different altitudes of the two sites, with Glaciar La Ollada being $800 \mathrm{~m}$ higher. Originally, mean summer temperatures of $-6^{\circ} \mathrm{C}$ and $-11^{\circ} \mathrm{C}$ for Esmeralda and La Ollada glaciers, respectively, were expected, based on temperature extrapolation $\left(6.5^{\circ} \mathrm{C}(1000 \mathrm{~m})^{-1}\right)$ from the nearest high-altitude meteorological station, Cristo Redentor $\left(32.82^{\circ} \mathrm{S}, 70.07^{\circ} \mathrm{W} ; 3852 \mathrm{ma.s.l}.\right)$. The intense melting observed on Glaciar Esmeralda is in disagreement with the estimated summer temperatures of $-6^{\circ} \mathrm{C}$. However, extrapolation is difficult, as there is a strong north-south gradient in that area. At Cerro Tapado, located $150 \mathrm{~km}$ further north, mean summer temperatures (recorded from 15 December 1998 to 15 February 1999 ) were $-2.8^{\circ} \mathrm{C}$ at $5260 \mathrm{~m}$ and $+5.0^{\circ} \mathrm{C}$ at $4215 \mathrm{~m}$ (Ginot and others, 2001). Mean January temperatures of $+4^{\circ} \mathrm{C}$ at $4720 \mathrm{~m}$ were measured at the Agua Negra pass $\left(30^{\circ} \mathrm{S}\right)$ (Schrott, 1994), and strong melting was observed on Glaciar Agua Negra, which extends between 5200 and 4600 ma.s.l. (Milana and Maturano, 1999).

A puzzling stratigraphic feature of the core from Glaciar La Ollada is the layers of visible coarse particles. These particles must originate from snow/ice-free slopes around the glacier. However, the glacier surface is relatively flat and the drilling site is $>400 \mathrm{~m}$ away from the margins of the glacier. Thus, several prerequisites exist for their formation: strong storms blowing coarse particles over the glacier are needed, the glacier surface must be hard to allow for particle saltation and suspension (Nishimura and Hunt, 2000), and the edges of the glacier need to be snow/ice-free (late summer). Hence, extreme conditions seem to occur from time to time on Mercedario.

\section{CONCLUSION}

The well-preserved glaciochemical signal at Glaciar La Ollada is very promising for obtaining a longer time record. A new core was drilled to $104 \mathrm{~m}$ depth in February 2005. This record should provide high-resolution paleoclimate data from a region strongly influenced by the ENSO in such a way that El Niño years coincide with higher values of winter precipitation. Past ENSO-related climate variations in this region are poorly documented due to the scarcity of suitable archives. However, it cannot yet be estimated how far back in time the information provided by the new record will go. Given the estimated annual net accumulation rate of $0.45 \mathrm{~m}$ w.e. together with a core length of $104 \mathrm{~m}$, a severalcentury record should be contained. An upper limit for the age at bedrock cannot be given, as the thinning rate is difficult to predict. An ice core from Quelccaya ice cap, Peru, (Thompson and others, 1985) was slightly longer $(163.6 \mathrm{~m})$, and the ice at bedrock was 1500 years old (the annual-layer thickness was $1.2 \mathrm{~m}$ ice equivalent at the surface). Another core, from Col de Huascarán, Peru, was $166.1 \mathrm{~m}$ long, with an annual-layer thickness of 

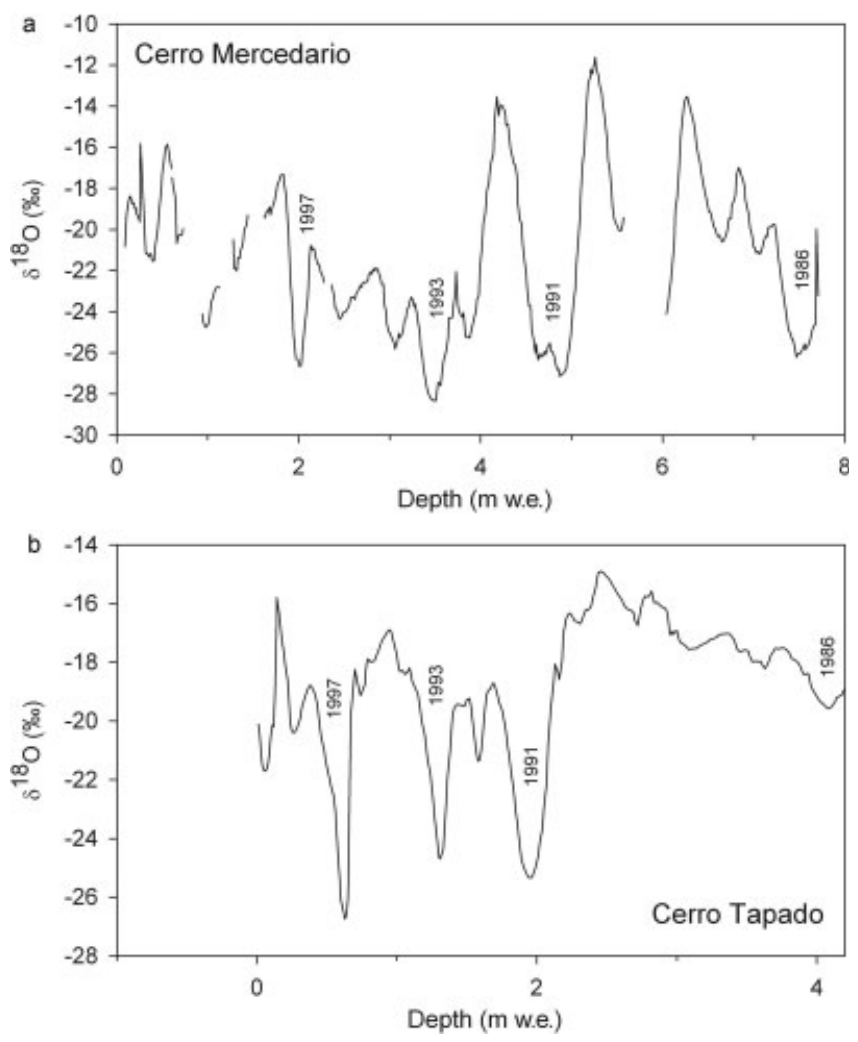

Fig. 9. $\delta^{18} \mathrm{O}$ records of Cerro Mercedario (a) and Cerro Tapado (b), representing a comparable time interval.

around $1.5 \mathrm{~m}$ ice equivalent and ice dating back to the late glacial stage (dated $19000 \mathrm{BP}$ ) (Thompson and others, 1995). The core from Illimani, Bolivia, with an annual accumulation rate of $0.58 \mathrm{~m}$ w.e. and a length of $138.7 \mathrm{~m}$, covered approximately the last 18000 years (Knüsel and others, 2003; Ramirez and others, 2003).

The finding that Glaciar Esmeralda, despite being located at $5300 \mathrm{~m}$ a.s.l. in the subtropics, is strongly influenced by meltwater formation and percolation underlines again how threatened these valuable archives are by current global warming and how important it is to investigate them before they become unsuitable or disappear.

\section{ACKNOWLEDGEMENTS}

Financial support from the Swiss National Science Foundation (grant No. 200021-100289) is gratefully acknowledged. G.C. and A.R. were sponsored partially by Fondo Nacional de Ciencia y Tecnología of Chile (FONDECYT 1040989) and Centro de Estudios Científicos (CECS). CECS is funded in part by the Millennium Science Initiative and grants from Empresas CMPC, Andes and Tinker Foundations. Thanks to B. Rufibach for drilling, F. Contreras, G. Cabrera and A. Mirando for support in the field, and M. Saurer, R. Siegwolf and D. Theiss for helping with the isotope-ratio mass spectrometer.

\section{REFERENCES}

Aceituno, P. 1988. On the functioning of the Southern Oscillation in the South American sector: Part 1. Surface climate. Mon. Weather Rev., 116, 505-524.
Baltensperger, U. and 6 others. 1997. Aerosol climatology at the high-alpine site Jungfraujoch, Switzerland. J. Geophys. Res., 102(D16), 19,707-19,716.

Bradley, R.S., M. Vuille, D. Hardy and L.G. Thompson. 2003. Low latitude ice cores record Pacific sea surface temperatures. Geophys. Res. Lett., 30(4), 1174. (10.1029/2002GL016546.)

Crozaz, G. and C.C. Langway, Jr. 1966. Dating Greenland firn-ice cores with Pb-210. Earth Planet Sci. Lett., 1, 194-196.

Eichler, A. and 7 others. 2000. Glaciochemical dating of an ice core from upper Grenzgletscher (4200 m a.s.l.). J. Glaciol., 46(154), 507-515.

Escobar, F. and P. Aceituno. 1998. Influencia del fenómeno ENSO sobre la precipitación nival en el sector andino de Chile Central durante el invierno austral. Bull. Inst. Fr. Étud. Andin., 27(3), 753-759.

Escobar, F., G. Casassa and V. Pozo. 1995. Variaciones de un glaciar de Montaña en los Andes de Chile central en las últimas dos décadas. Bull. Inst. Fr. Étud. Andin., 24(3), 683-695.

Gäggeler, H., H.R. von Gunten, E. Rössler, H. Oeschger and U. Schotterer. 1983. ${ }^{210} \mathrm{~Pb}$-dating of cold Alpine firn/ice cores from Colle Gnifetti, Switzerland. J. Glaciol., 29(101), 165-177.

Ginot, P., C. Kull, M. Schwikowski, U. Schotterer, B. Pouyaud and H.W. Gäggeler. 2001. Effects of post-depositional processes on snow composition of a subtropical glacier (Cerrado Tapado, Chilean Andes). J. Geophys. Res., 106(D23), $32,375-32,386$.

Ginot, P., F. Stampfli, D. Stampfli, M. Schwikowski and H.W. Gäggeler. 2002a. FELICS, a new ice core drilling system for high-altitude glaciers. Natl. Inst. Polar Res. Mem. 56, Special Issue, 38-48.

Ginot, P. and 7 others. 2002b. Potential for climate variability reconstruction from Andean glaciochemical records. Ann. Glaciol., 35, 443-450.

Henderson, K.A., L.G. Thompson and P.N. Lin. 1999. Recording of El Niño in ice core $\delta^{18} \mathrm{O}$ records from Nevado Huascarán, Peru. J. Geophys. Res., 104(D24), 31,053-31,065.

Hoffmann, G. and 11 others. 2003. Coherent isotope history of Andean ice cores over the last century. Geophys. Res. Lett., 30(4), 1179. (10.1029/2002GL014870.)

Knüsel, S. and 8 others. 2003. Dating of two nearby ice cores from the Illimani, Bolivia. J. Geophys. Res., 108(D6), 4181. (10.1029/ 2001JD002028.)

Kull, C. and M. Grosjean. 2000. Late Pleistocene climate conditions in the north Chilean Andes drawn from a climateglacier model. J. Glaciol., 46(155), 622-632.

Leiva, J.C. 1999. Recent fluctuations of the Argentinian glaciers. Global Planet. Change, 22(1-4), 169-177.

Milana, J.P. and A. Maturano. 1999. Application of radio echo sounding at the arid Andes of Argentina: the Agua Negra Glacier. Global Planet. Change, 22(1-4), 179-191.

Narod, B.B. and G.K.C. Clarke. 1994. Miniature high-power impulse transmitter for radio-echo sounding. J. Glaciol., 40(134), 190-194.

Nishimura, K. and J.C.R. Hunt. 2000. Saltation and incipient suspension above a flat particle bed below a turbulent boundary layer. J. Fluid Mech., 417, 77-102.

Paterson, W.S.B. 1994. The physics of glaciers. Third edition. Oxford, etc., Elsevier.

Ramírez, E. and 12 others. 2003. A new Andean deep ice core from Nevado Illimani $(6350 \mathrm{~m})$, Bolivia. Earth Planet. Sci. Lett., 212(3-4), 337-350.

Rivera, A. and G. Casassa. 2002. Detection of ice thickness using radio-echo sounding on the Southern Patagonia Icefield. In Casassa, G., F.V. Sepúlveda and R. Sinclair, eds. The Patagonian icefields: a unique natural laboratory for environmental and climate change studies. New York, Kluwer Academic/Plenum Publishers, 101-115.

Rivera, A., G. Casassa and C. Acuña. 2001. Mediciones de espesor en glaciares de Chile centro-Sur. Rev. Invest. Geogr., 35, 67-100. 
Schneider, C. and D. Gies. 2004. Effects of El Niño-Southern Oscillation on southernmost South America precipitation at $53^{\circ} \mathrm{S}$ revealed from NCEP-NCAR reanalyses and weather station data. Int. J. Climatol., 24(9), 1057-1076.

Shrott, L. 1994. Die Solarstrahlung als steuernder Faktor im Geosystem der Subtropischen semiariden Hochanden (Agua Negra, San Juan, Argentina). (PhD dissertation, University of Heidelberg.)

Thompson, L.G., E. Mosley-Thompson, J.F. Bolzan and B.R. Koci. 1985. A 1500-year record of tropical precipitation in ice cores from the Quelccaya ice cap, Peru. Science, 229(4717), 971-973.

Thompson, L.G. and 7 others. 1995. Late Glacial stage and Holocene tropical ice core records from Huascarán, Peru. Science, 269(5220), 46-50.

Veit, H. 2000. Klima- und Landschaftswandel in der Atacama. Geogr. Rundsch., 52(9), 4-9.
Videla, M.A. 1997. Neoglacial advances in the Central Andes, Argentina, during the last centuries. Quat. S. America Antarct. Penin., 10, 55-70.

Vose, R.S. and 6 others. 1992. The global historical climatology network: long-term monthly temperature, precipitation, sea level pressure, and station pressure data. Oak Ridge, TN, Oak Ridge National Laboratory. Carbon Dioxide Information Analysis Center.

Vuille, M., R.S. Bradley, M. Werner, R. Healy and F. Keimig. 2003 a. Modeling $\delta^{18} \mathrm{O}$ in precipitation over the tropical Americas: 1. Interannual variability and climatic controls. J. Geophys. Res., 108(D6), 4174. (10.1029/2001JD002038.)

Vuille, M. and 6 others. 2003b. Modeling $\delta^{18} \mathrm{O}$ in precipitation over the tropical Americas: 2. Simulation of the stable isotope signal in Andean ice cores. J. Geophys. Res., 108(D6), 4175. (10.1029/2001JD002039.) 